66『コンピュータグラフィックスによる照明シミュレーション』 〜 昼光解析への応用

作間久義広川純一秋場稲美五十里朋子土屋幸治

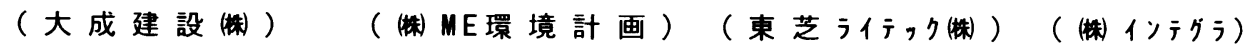

1.まえがき

最近では住環境の多用化が急速に進んでおり、それに伴い照明計画の新しい試みが 多くの物件で行われているのは周知の通りである。又、地下空間の利用や建物の密集 地域での計画の場合、採光についてクライアントの関心は非常に強くそして採光を含 めた照明計画は容易ではない。難しい問題の一つとしてクライアントへの説明が挙げ られる。なせなら、照明分布図などでは出来上がりのイメージをとらえ難いし、模型 で昼光を扱おうとするとかなり大きな装置を必要としてしまうからだ。そこで我々は 昭和 62 年 12 月に導入して以来、数々の人エ照明による環境解析で実績をあげているRe mbradt (レンフラント)SYSTEM（愛称）を利用し、昼光解析への応用を行ったのでその内容を 報告する。

2. システム概 要

$2-1$ ソフトゥエアーについて

当システムは、主にモデラ一、解析、レンダラー、データベースから構成される。

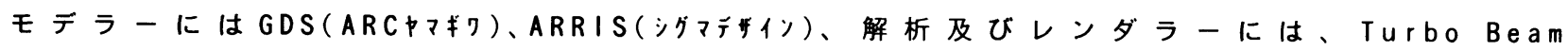

Tracing( TBT-1ンテララ)を使用している。解析はモテラーで構築された建物 (3D)形状デ 一タをコンバージョンし、解析及ひレンダラーに取り込むことにより行う。又、双方 向レイ・トレーシング法により、拡散相互反射、鏡面反射、透過及ひ屈折が扱え、出 カモードとして、写真の様なイメージ、カラーコンターによる照度、輝度分布が選択 できる。

解析に必要なテータは、建物データの他にプリミティブの光学特性值（拡散反射率 鏡面反射率、透過率、屈折率、ハイライト係数）、光源の位置テータ及ひ、、光源の配 光データなどである。これらのデータは、テータベースより選択しセットする。

2 - 2 八ードゥェアーについて

IRIS4D/220GTX(シリコンクラフィクス)

3 . 昼光解析

前述の通り、当システムでは光源情報を与えさえすれば、 各反射モデルに従い正確にシミュレイト出来るので、直射 成分及び天空光成分を構成する光源群の情報を用意すれば よいことになる。

まず、計算は天球（半径 $1.2 \times 10^{5} \mathrm{~m}$ )を仮想し、それを 151 枚の素面に分割することから始まる。151分割するこ とに関しては、RIBA MCIBSEの理論をそのまま利用した。（図一 1 )

次に太陽の位置を計算し、その值から天球の相対輝度分布を算出する。ここで算出 式にはCIE 標準晴天空; 標準曇天空の相対輝度分布算出式を利用した。こに天頂輝 度を与えた上で、各面素の面積を与え光度を得る。求まった 151 個の光度値と位置情 報を利用し、双方向レイ・トレーシング法により全天空光の解析が可能よなる。又、 晴天時においては太陽のデータを付加することよって昼光解析が可能である。太陽デ 一タについては、理科年表にある太陽諸定数を利用した。

Lighting simulation based on bidirectional ray tracing-apply to day lightHisayosi Sakuma, Jun-ichi Hirokawa, Inami Akiba, Tomoko Ikari, Kouji Tsuchiya 


\section{4. 解析結果}

$4-1$ 水平面照度

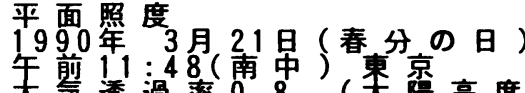

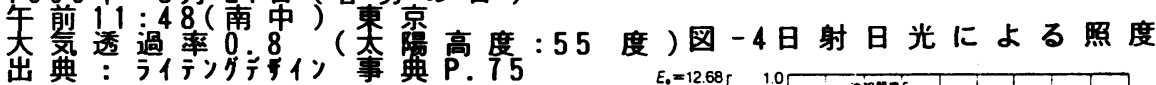

図一 2 解析值と参考値の比較

\begin{tabular}{|c|c|c|c|c|}
\hline & 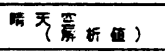 & 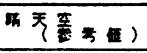 & 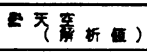 & 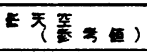 \\
\hline Eた头のみ & क $83.2008 x$ & क $83.000 \& x$ & - & - \\
\hline 天互光のみ & to $19.5002 x$ & $\begin{array}{l}11.000 \sim \\
26.000 \& \times\end{array}$ & * $20.4002 \times$ & $\begin{array}{l}* 10.000 \sim \\
26.0000 \Omega\end{array}$ \\
\hline 光 & $102.7008 x$ & - & - & - \\
\hline
\end{tabular}

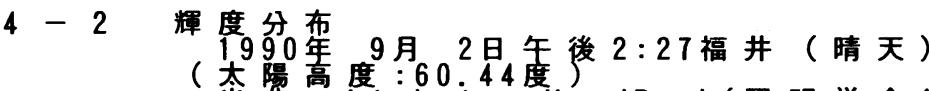

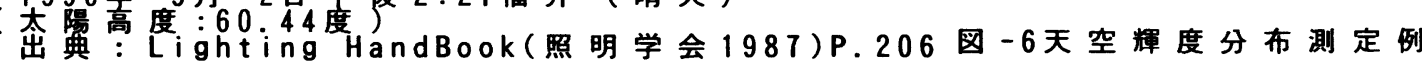

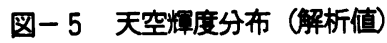

\begin{tabular}{|c|c|c|c|c|c|c|c|c|c|c|c|c|c|c|c|c|}
\hline i v & 1 & 2 & 3 & 4 & 5 & 6 & 7 & 8 & 9 & 10 & 11 & 12 & 13 & 11 & 15 & 16 \\
\hline 1 & 41 & & & & & & & & & & & & & & & \\
\hline 2 & 64 & 47 & 31 & & & & & & & & & & & & & \\
\hline 3 & 101 & 76 & 52 & 39 & 33 & 30 & & & & & & & & & & \\
\hline 4 & 188 & 123 & 81 & 57 & 43 & 36 & 31 & 29 & 29 & & & & & & & \\
\hdashline 5 & 262 & 111 & 114 & 80 & 60 & 48 & 40 & 36 & 33 & 31 & 31 & 31 & & & & \\
\hline 6 & 214 & 114 & 130 & 98 & 76 & 61 & 51 & 44 & 41 & 39 & 39 & 38 & 38 & 38 & & \\
\hline 7 & 188 & 161 & 138 & 111 & 91 & 76 & 64 & $\frac{58}{58}$ & 54 & 52 & 51 & 51 & 52 & 53 & 53 & \\
\hline 8 & 188 & 116 & 156 & 134 & 116 & 100 & 89 & 82 & 78 & 76 & 76 & 78 & 80 & 82 & 86 & 84 \\
\hline
\end{tabular}

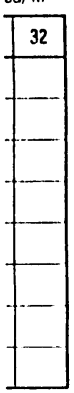

5 . 考察
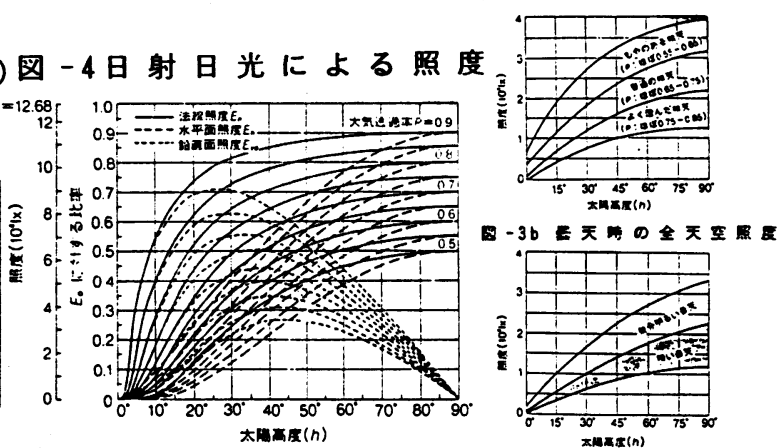

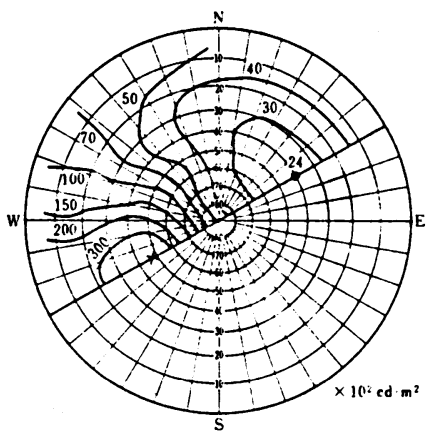

1967 म: $9 / 12$ 日, 情非

解析の結果、解析値と参考值はほほ一致しており赛用上問題ないと考えられる。し かし、今回の解析を行うにあたって、解析ソフトのテータフォーマットにあわせる為 に輝度分布を光度分布に变換する必要がり、素面面積を計算する時に誤差か生して いる可能性がある今後は輝度分布から直接照度を計算できる様に改良し再度検討し てみたい。又、解析結果については実測值との比较か必要であり、実施物件で対応し たいと考えている。

最後に、今回作成したプログラムはRembrandt SYSTEMの 1 モジュールにすきす、 内容についても現存する方程式を組合せただけのものである。我々かやろうとしてい ることは、CGを利用した照明テザインであり今回のプログラムも含めて、いかに自然 光を、いかに人エ光をコーティネイトするかである。つまり熟考すへき点はそこにあ り照明計画の1つのッールとして利用していきたいと考えている。又、特に近年增え ている膜構造物やアトリゥムなどの大空間、大深度地下利用、海洋; 宇宙開発、防災 計画、などにも積極的に利用していきたいと考えている。

6 . 謝 辞

本件に関し御協力頂いたインテグラ、東芝ライテック社の方々に心より謝意 を表します。

7. 参考文献

- 「昼光の有効利用を目的とする建築照明計算法の研究」

(昭和 62 年度研究成果報告書) 九州大学工学部建築学科 中村洋教授

- r subdivision of the sky hemisphere for luminance measurements $\rfloor$

( Lighting Res Technol(1987)13-14)

RIBA MCIBSE

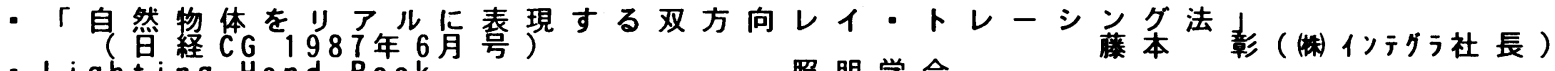
: Lighting Hand Book

暒膳学会会 